\title{
THE INFLUENCE OF RELIGIOSITY, ECONOMIC PRESSURE, FINANCIAL MANAGEMENT, AND STRESS LEVELS TOWARDS FAMILY QUALITY OF LIFE DURING COVID-19 PANDEMIC IN INDONESIA
}

\author{
Rana Chyntia Azzara ${ }^{1 *}$, Megawati Simanjuntak², Herien Puspitawati ${ }^{2}$ \\ ${ }^{1}$ Program Studi Magister Ilmu Keluarga dan perkembangan Anak, Sekolah Pascasarjana, \\ IPB University, Bogor 16880, Indonesia \\ ${ }^{2}$ Department of Family and Consumer Sciences, Faculty of Human Ecology, \\ IPB University, Bogor 16680, Indonesia \\ *)E-mail: ranachyntiaa@gmail.com
}

\begin{abstract}
An increased number of coronavirus cases infection has resulted in instability of household, which has an impact on family quality of life (QoL), and the facts during Covid-19 pandemic are contrary to the structural-functional theory, which emphasizes system stability and balance. This study aims to analyze the effect of religiosity, economic pressure, stress levels, and family management on family QoL during the Covid-19 pandemic and to analyze family typology based on stress levels, economic pressure, and family QoL. This study uses a quantitative approach and voluntary sampling method with 270 respondents selected based on criteria of working mothers or homemakers with working husbands. The higher frequency of religiosity and the smaller the economic pressure, the lower risk of high-stress levels. The high-stress levels and economic pressure decrease the family QoL, but the QoL increase if the family can carry out good financial management. Increasing the frequency of religiosity would improve family QoL by reducing stress levels. The typology is dominated by economic pressure and low QoL, while the typology of stress level and balanced QoL is dominated by the best type (low-stress levels, high QoL) and both low types. Reduced economic pressure, improved financial management, and stress management are important to preserve or improve QoL.
\end{abstract}

Keywords: economic pressure, family, quality of life, religiosity, stress levels

\section{Pengaruh Religiosity, Tekanan Ekonomi, Tingkat Stres, dan Manajemen Keuangan terhadap Kualitas Hidup Keluarga Masa Pandemi Covid-19 Di Indonesia}

\begin{abstract}
Abstrak
Peningkatan jumlah kasus infeksi virus corona mengakibatkan ketidakstabilan kehidupan rumah tangga yang memiliki dampak langsung terhadap kualitas hidup keluarga, serta fakta kehidupan masa pandemi Covid-19 ini bertolak belakang dengan teori struktural fungsional yang menekankan kestabilan dan keseimbangan sistem. Penelitian ini bertujuan untuk menganalisis pengaruh religiositas, tekanan ekonomi, tingkat stres, dan manajemen keluarga terhadap kualitas hidup keluarga pada masa pandemi Covid-19, dan menganalisis tipologi keluarga berdasarkan tingkat stres tekanan ekonomi, dan kualitas hidup keluarga. Penelitian ini menggunakan pendekatan kuantitatif dan metode voluntary sampling dengan total 270 responden yang diseleksi berdasarkan kriteria ibu bekerja atau ibu rumah tangga dengan suami bekerja. Semakin tinggi frekuensi religiositas dan semakin kecilnya tekanan ekonomi, maka akan menurunkan kemungkinan tingginya tingkat stres. Tingginya tingkat stres dan tekanan ekonomi akan berdampak pada penurunan kualitas hidup keluarga, namun kualitas hidup akan meningkat jika keluarga melakukan manajemen keuangan yang baik. Peningkatan frekuensi religiositas akan memperbaiki kualitas hidup melalui penurunan tingkat stres. Tipologi didominasi oleh tekanan ekonomi dan kualitas hidup keduanya rendah, sedangkan tipologi tingkat stres dan kualitas hidup seimbang didominasi oleh tipe terbaik (tingkat stres rendah, kualitas hidup tinggi) dan tipe keduanya rendah. Untuk mempertahankan atau memperbaiki kualitas hidup perlu mengurangi tekanan ekonomi, memperbaiki cara manajemen keuangan, dan pengelolaan stres yang baik.
\end{abstract}

Keywords: keluarga, kualitas hidup, religiusitas, tekanan ekonomi, tingkat stres

\section{INTRODUCTION}

The Covid-19 pandemic has a massive impact on the human life sector, particularly household life, and can be measured or seen through factors that affect the family quality of life (QoL), such as religiosity, economic pressure, stress, and financial management. According to the WHO (2021), Covid-19 is an infectious disease caused by a coronavirus. For example, the 
virus is easily infected through saliva droplets, especially in humans with low immunity levels. BPS (2020) attached that the national Human Development Index only increased by 0.03 percent. A decrease influences the Purchasing power parities (PPP) by 2.53 percent due to the weakening of the family economy during the pandemic (OECD, 2021). Gibson and Olivia (2020) revealed, decreased consumption during the Covid-19 pandemic resulted in (causes) a national poverty rate increase of about 9.78 percent (26.42 million people). In addition, there have been irregularities or imbalances in life, such as work and education fields (Hanoatubun, 2020; Syah, 2020). These things affect the family QoL during the Covid- 19 .

According to the structural-functional and system theory, the changes during the Covid-19 pandemic disturb the stability and balance of the family system (Puspitawati, 2012). In particular, various threats ranging from physical/psychological and economic health can emotionally impact QoL. For this reason, according to $\mathrm{ABC}-\mathrm{X}$ theory, families must have the capacity to avoid or deal with family crises (Maryam, 2017). One of the consequences of the crisis is the emergence of stress symptoms such as physical, psychological, and behavioral, and it requires a coping strategy to deal with changing demands during the Covid19 pandemic (Rosino, 2016). Religiosity and sound financial management are coping strategies by utilizing family values and capacities to adapt to stressful events (Carroll et al., 2020; Sakellari et al., 2017).

Buana (2020) revealed that meditation and worship at home could increase life expectancy and see the positive side of life. It means that families can still experience a good QoL even in the conditions of the Covid-19 pandemic. Rahmah's (2018) findings state that religiosity factors contribute positively to the development of life. Individuals with high religiosity will tend to accept the situations and conditions they experience because they appreciate religious values to form high QoL. In addition, high religiosity will reduce symptoms of depression and form better mental health (Burlacu et al., 2019).

In addition to improving the QoL through religiosity, the families of Covid-19 survivors are also expected to avoid economic pressure. Economic pressure influences the QoL subjectively and objectively (Kumalasari, Herawati, \& Simanjuntak, 2018). When the family's economic pressure is high, it tends to increase symptoms of depression, which leads to high levels of stress (Sarrasin, Green, Potarca, Bolzman, \& Kuhn, 2019). In addition, stress as a significant predictor of QoL is related to physical and mental health. By the ABC- $X$ theory of stress, families will survive if they face life transitions (Azizah \& Hartanti, 2016). Furthermore, financial problems due to confusion in managing finances are also a major trigger for stress, and if it occurs continuously, it will result in a decline in the family QoL. Furthermore, high economic pressure, stress levels, and low financial management will result in low family QoL.

Special research on religiosity has been studied by Megawaty (2016) as well as Muhammad, Muflikhati, and Simanjuntak (2019), economic pressure by Kumalasari et al. (2018), financial management by Chae, Park, and Jang (2020), and stress levels by Hsiao, Higgins, Pierce, Whitby, and Tandy (2017), but the subjects studied were not families of Covid-19 survivors. Previous research has proven that several factors influence religiosity, stress levels, financial management, economic status, so all these variables can affect QoL.

Khodijah's (2018) research found that things that affect religiosity are 1) gender, 2) educational experience, 3) family atmosphere, and 4) socioeconomic status. Furthermore, Lady, Susihono, and Muslihati (2017) reveal that several things affect stress levels, namely 1) personality, 2) conflict, 3) lack of control, and 4) much workload. Then, previous research found that education, knowledge, and environment influenced family financial management (Hakim, Sunarti, \& Herawati, 2014). Then, research during the Covid-19 pandemic found factors that affect the QoL, namely family support, socioeconomic status, family resilience, and government assistance programs.

Based on this description, the family QoL during the Covid-19 pandemic was disrupted based on previous studies. However, from previous studies reviewed through other criteria, many other determinants of QoL have not been studied. There is not much research on the family QoL of Covid-19 survivors, especially in religiosity, economic pressure, financial management, and stress levels. Various changes experienced by families during the Covid-19 pandemic is essential and exciting study to measure families' QoL so that the government and families can also evaluate and improve their competence. 


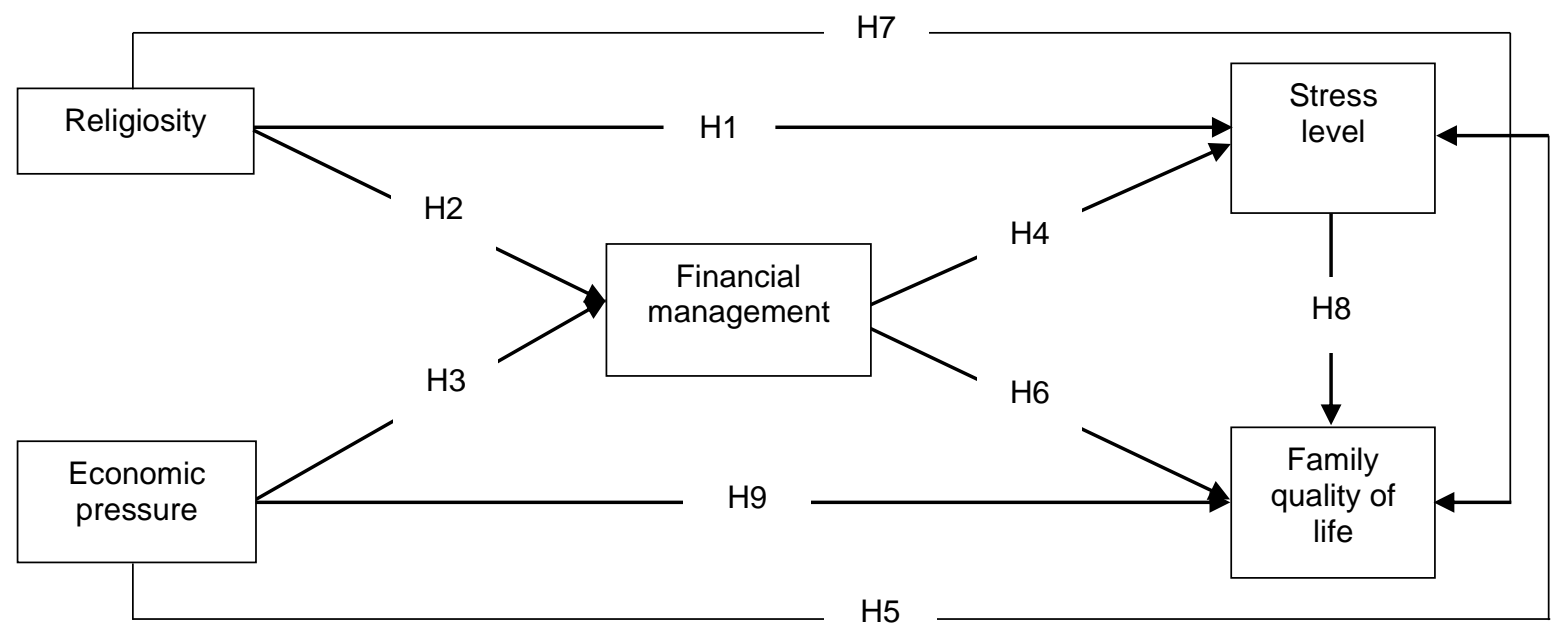

Figure 1 An empirical framework of factors affecting the family quality of life

This study aims to analyze the influence of religiosity, economic pressure, financial management, and stress levels on the family QoL and analyze family typology based on stress levels, economic pressure, and family QoL during the Covid-19 pandemic. This research is expected to provide benefits and contributions to various groups, including a reference for further research. For families, this study can be used as material for selfevaluation to improve the mother's competence to each individual in the family and the relationships between individuals in it, especially between husbands, wives, and children. This research is expected to provide helpful information related to religiosity, economic pressure, stress levels, financial management, and the QoL during the Covid-19 pandemic for the wider community.

The related variable in this study is quality of life (Y1). The independent variables include religiosity (X1), economic pressure (X2), financial management $(X 3)$, and stress level (X4). The conceptual and empirical framework of the factors that influence the family QoL based on the literature review is presented in Figure 1. In this study, the hypothesis that tested is:

H1 : religiosity has a significant negative effect on stress levels

H2 : religiosity has a significant positive impact on financial management

H3 : economic pressure has a significant negative impact on financial management

$\mathrm{H} 4$ : financial management has a significant negative effect on stress levels

H5 : economic pressure has a significant positive effect on stress levels

H6 : financial management has a significant positive effect on the quality of life
H7 : religiosity has a significant positive effect on the quality of life

$\mathrm{H8}$ : stress level has a significant negative impact on the quality of life

H9 : economic pressure has a significant negative impact on the quality of life

\section{METHODS}

Quantitative research was collected using online questionnaires with 270 respondents, and it was taken in December 2020 and distributed almost all over Indonesia. Based on the Covid-19 Handling Task Force (2020) data, almost all islands in Indonesia expose to the coronavirus. The unit of analysis in this study was the family, and the respondent was housewives. The determination of samples was carried out using non-probability sampling methods with voluntary sampling. The questionnaires were distributed through social media platforms such as WhatsApp, Twitter, and Instagram (Pace, 2021). The variables of religiosity, economic pressure, financial management, and stress levels were measured using the same Likert scale with a range of 1 to 4 ( 1 for never, 2 for rarely, 3 for often, and 4 for always).

Religiosity is the frequency of the family in carrying out religious activities. This religiosity variable measuring instrument was developed independently based on Islamic principles. The measurement involves 8 question items with Cronbach's alpha value of 0.720 .

Economic pressure is defined as a perceived problem regarding the family's perception of financial problems. The economic pressure variable questionnaire refers to Lorenz, Conger, and Montague (2020), consisting of 7 question 
items with a Cronbach's alpha value is 0.703 .

Financial management is defined as the use of financial resources owned by the family. The measurements were referenced and modified from Hakim et al. (2014) involved 10 question items consisting of planning dimensions (4 questions), implementation dimensions (3 questions, and evaluation dimensions (3 questions), and the Cronbach's alpha value of this instrument was 0.903 .

Stress level is an assessment of stress through stress symptoms in terms of attitudes and inner feelings towards the presence of a stressor. The stress level variable questionnaire refers to Maulana and Iswari (2020). The Cronbach's alpha value is 0.909 and consists of 12 question items.

Quality of life is defined as the family's perceived satisfaction in life. The QoL questionnaire refers to The World Health Organization Quality of Life (WHOQOL-BREF) (2004) with Cronbach's alpha value of 0.832 . A total of 13 question items with a Likert scale of 1 to 5 ( 1 for strongly disagree, 2 for disagree, 3 for neutral, 4 for agree, and 5 for strongly agree).

Data were analyzed descriptively and Structural Equation Modeling (SEM). The analysis was carried out using SPSS 25.0 and LISREL 8.7 tools. Statistical analysis method, namely descriptive analysis, was used to describe the characteristics and variables studied in the form of average, standard deviation, minimum value, and maximum value of the data distribution. SEM analysis was used to answer the research objectives and determine the effect of religiosity, economic pressure, financial management, and stress levels on the quality of family life.

\section{RESULT}

\section{Family Characteristics}

Respondent's Age and Education. The analysis units in this study were housewives and working mothers. The average age of mothers in this study was 36.8 years in the early adult category (63.7\%), 18 to 40 years old. In addition, most respondents $(72.6 \%)$ have more than 12 years of education, categorized as college education. Besides, 58.5 percent of the study's respondents were working, and 41.5 percent of the mothers in the study were housewives.
Table 1 Comparison of income and expenses, as well as assets and debts

\begin{tabular}{|c|c|c|}
\hline Category & $\begin{array}{l}\text { Number } \\
\text { (n) }\end{array}$ & $\begin{array}{c}\text { Percentage } \\
(\%)\end{array}$ \\
\hline \multicolumn{3}{|c|}{ Comparison of income and expenses } \\
\hline Expenses > Income & 114 & 42.2 \\
\hline Expenses $=$ Income & 78 & 28.9 \\
\hline Expenses $<$ Income & 78 & 28.9 \\
\hline \multicolumn{3}{|c|}{ Comparison of assets and debts } \\
\hline $\begin{array}{l}\text { Debt > Half of Wealth } \\
\text { Value }\end{array}$ & 61 & 22.6 \\
\hline $\begin{array}{l}\text { Debt < Half of Wealth } \\
\text { Value }\end{array}$ & 80 & 29.6 \\
\hline No Debt & 129 & 47.8 \\
\hline
\end{tabular}

Source: Primary data from October to December 2020

Income, Expenses, Assets, and Debt. Table 1 shows that less than half of the families (42.2\%) have bigger expenditures than income. It means many families still lack control over spending to exceed their income limit. The comparison of expenses equals income and expenses less than income classified as less than 30 percent. Also, the comparison of assets and debts to the sample family $(47.8 \%)$ is classified as indebted. It means that quite several families have realized that it is better to avoid debt.

\section{Factors Affect the Family Quality of Life}

Based on the SEM model proposed in this study, testing the $\mathrm{H} 1$ to $\mathrm{H} 9$ hypothesis can be done through path coefficient $(\leq 0.05)$ and $t-$ value $(\geq 1.96)$. Table 2 shows the SEM model hypothesis test results in direct, indirect, and total effects.

Table 2 Results of effects decomposition for latent variables of quality of life

\begin{tabular}{lccc}
\hline \multicolumn{1}{c}{ Variable } & DE & IE & TE \\
\hline $\begin{array}{l}\text { Financial management } \\
\left(\eta_{2}\right)\end{array}$ & & & \\
Religiosity $\left(\eta_{1}\right)$ & 0.13 & 0.00 & 0.13 \\
Economic pressure $\left(\xi_{1}\right)$ & -0.09 & 0.00 & -0.09 \\
Stress levels $\left(\eta_{3}\right)$ & & & \\
Religiosity $\left(\eta_{1}\right)$ & $-0.19^{*}$ & 0.00 & $-0.19^{*}$ \\
$\begin{array}{l}\text { Financial management } \\
\left(\eta_{2}\right)\end{array}$ & 0.01 & 0.00 & 0.01 \\
Economic pressure $\left(\xi_{1}\right)$ & $0.51^{*}$ & 0.00 & $0.51^{*}$ \\
Quality of Life $\left(\eta_{4}\right)$ & & & \\
Religiosity $\left(\eta_{1}\right)$ & 0.06 & $0.06^{*}$ & $0.12^{*}$ \\
Financial management \\
$\left(\eta_{2}\right)$
\end{tabular}

Note: $\mathrm{DE}=$ Direct Effect; IE=Indirect Effect; TE=Total Effect; *significant at $p<0.05$ 
Stress levels are significantly affected by religiosity negatively, and economic pressure is significantly positive. It means that an increase in the frequency of worship and a decrease in economic pressure will prevent increased stress. Economic pressure, financial management, and stress levels significantly affect the QoL. It means that increased economic pressure, poor financial management, and high family stress levels will decrease the family QoL.

Two variable pathways affect the QoL through the endogenous latent variable, namely religiosity and the exogenous latent variable, namely economic pressure. Religiosity has an effect of 3.61 percent, and economic pressure affects 26.01 percent of stress levels. High economic pressures cause stress levels to rise. On the other hand, a person with a high level of religiosity will have low-stress levels. The family QoL is positively influenced by financial management by 2.89 percent, negatively by economic pressure by 5.29 percent, and negatively by stress levels by 10.24 percent. It means that higher financial management will make family QoL better. However, increased stress and economic pressure will decrease QoL.

Indirectly, religiosity can influence the QoL through a stress level of 6.08 percent. Although the results found that religiosity does not directly affect QoL, increasing the frequency of worship avoids stress, so it will also impact the increase in QoL. In addition, economic pressure can also indirectly affect the QoL through a stress level of 16.32 percent. In contrast to religiosity, the existence of economic pressure increases stress so that it has an impact on QoL assessment. Therefore, based on the description, the most effective entry route is economic pressure, affecting the QoL directly or indirectly.

\section{Family Typology}

Family typology in this study is distinguished into two, namely family typology based on economic pressure and QoL and stress levels and QoL. First, the typology of economic pressure is seen based on the distribution of categories of economic pressure and QoL. Based on Figure 2, the horizontal line depicting economic pressure will worsen if the provisions go left. On the other hand, the vertical line describes the higher QoL if the condition is getting upwards.

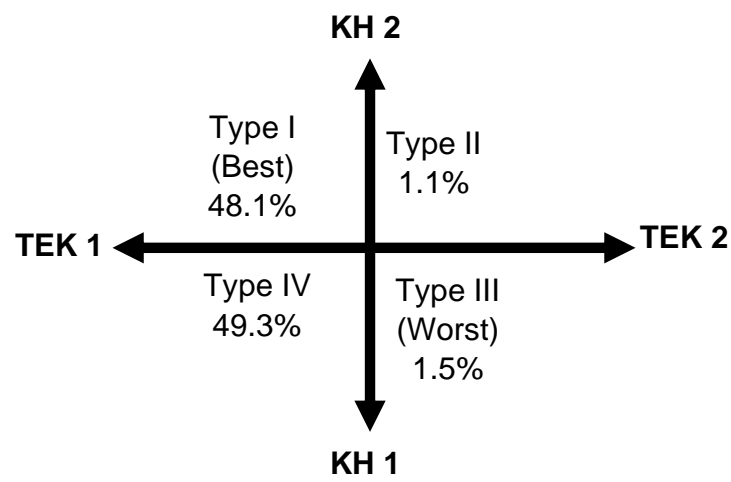

Note: $\mathrm{KH}=$ Quality of Life; TEK=Economic Pressure; $\mathrm{KH}$ 1=Low QoL; KH 2=High QoL; TEK 1=Low Economic Pressure; TEK 2=High Economic Pressure

Figure 2 Graph analysis of the typology of economic pressure and quality of life

Against Figure 2, families in type I are 48.1 percent, namely 130 families. This type explains the low economic pressure and high QoL. About 1.1 percent or three families are type II. Not much different from Type II, families experiencing Type III or are as much as 1.5 percent (4 families). Type IV indicates economic pressure and low QoL with 133 families $(49.3 \%)$.

The typology of stress levels and QoL is based on the distribution of stress levels and family QoL. Based on Figure 3, horizontal lines represent stress levels and vertical lines for QoL. The horizontal line shows that the stress level will lower if the point approaches the left. In contrast, the vertical line shows that the QoL increases if it goes upward. Type I and Type IV show most sample families in this study (48.5\%). Type II shows that as many as 0.7 percent of families. Type III is the worst type, with 2.3 percent of families experienced.

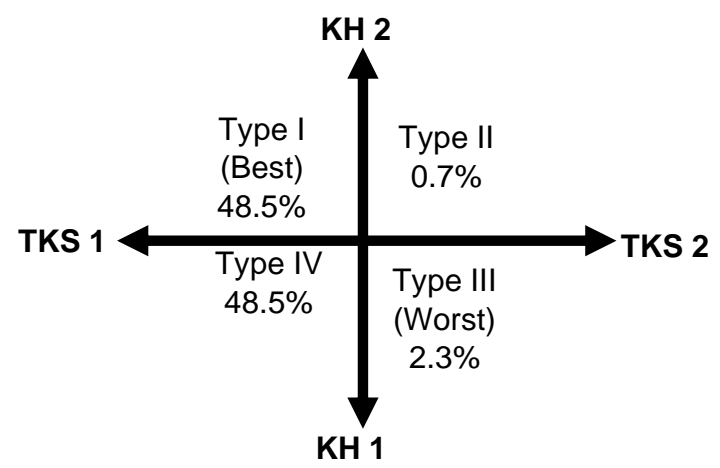

Note: $\mathrm{KH}=$ Quality of Life; TKS=Stress Levels; $\mathrm{KH} 1=\mathrm{Low}$ QoL; KH 2=High QoL; TKS 1=Low Stress Levels; TKS 2=High Stress Levels

Figure 3 Graph analysis of the typology of stress levels and quality of life 


\section{DISCUSSION}

The majority of the families of Covid-19 survivors have relatively high education, and the income they get is sufficient. In addition, most husbands and wives are classified as early adults. Dominant families have expenses greater than income, and this is because the expenditure is less controlled in fulfilling desires but tends to have fewer families who have debt. In addition, during the Covid-19 pandemic, religiosity has a role in reducing stress. Families who carry out religious activities regularly tend to feel less stressed. In contrast to economic pressure, this pandemic has made it difficult for many families economically due to limited mobility. However, some families also feel that their economic conditions do not burden them, so the possibility of stress due to economic pressure is relatively small. Financial management can act as a strategy to avoid economic pressure. The allocation of financial resources is more well-organized, expenditures can be regulated, and financial evaluation is carried out to improve financial management in the future. Then, the process of financial management and controlling economic pressure lead families to have a better QoL.

The findings of this study are that there is an influence between religiosity and stress levels. Conditions during the Covid-19 pandemic can harm mental health, and religiosity is a preventive measure to reduce stress symptoms and maintain psychological conditions. Religiosity that is not appropriately used tends to maintain symptoms of stress. During the Covid-19 pandemic, some families feel less fortunate in life, and if it is not balanced with closeness to God, it will be difficult to against thoughts that cause stress. Research by Pajarianto, Kadir, Galugu, Sari, and Februanti (2020) states that changes and transitions during Covid-19 can trigger stress and be suppressed by performing worship. Based on Bakht and Batool's (2018) research, increasing religiosity will prioritize belief in God that all events have benefits and not something in vain. This religiosity acts as a regular reminder to Muslims that Allah loves and facilitates any resources (material, mental, and emotional) to navigate daily life (Abu-Hilal, Al-Bahrani, \& AlZedjali, 2017).

This study did not find the effect of religiosity on financial management. Obedience in religion is not a benchmark to see the good or bad ways of managing family finances. The impact of poor financial management is debt and consumptive buying behavior, which is unrelated to family religious activities. This result is not in line with previous research, which states that religiosity can influence family financial governance and a preventive strategy for financial problems (Ahmad, Khairunnisa, \& Gurendawati, 2020; Lajuni, Bujang, Karia, \& Yacob, 2018). In addition, previous findings state concrete factors that affect financial management, such as financial knowledge, financial attitudes, and income (Nusron, Wahidiah, \& Budiarto, 2018). In addition, religiosity also does not affect economic pressure. By carrying out religious activities or worship, it is not merely a family benchmark in providing perceptions of the economic pressures during the Covid-19 pandemic. In contrast, Syafitri and Hadjam (2017) found that religiosity tends to act as a protective factor from stressors in the form of pressures.

Research shows that financial management is not affected by economic pressure. Families with economically depressed do not immediately carry out financial management to improve their economic conditions because in carrying out financial management, they need to have further knowledge and research on financial literacy. According to Herawati, Ginting, Asngari, Susanto, and Puspitawati (2011), educational factors generally influence economic pressure. However, the ability of families to manage finances is not always influenced by educational background but rather the critical role of environment, experience, and lifestyle. Stein et al. (2013) found that apart from family economic pressure, financial management does not significantly affect family pressure, but financial management can be a strategy to achieve high life satisfaction.

Doing financial management did not make low family stress levels. The factor that forms stress is the presence of stressors, while financial management is allocating finances, not stressors. According to Bawuna, Rottie, and Onibala (2017), families tend to be stressed if they experience difficult life changes, such as economic pressure. Following the findings show that economic pressure affects family stress levels. The Covid-19 pandemic has impacted the family's economic sector, such as decreased income, difficulties in meeting basic needs, and even job loss. Families that are economically depressed and do not have enough capacity or resources to deal with these pressures tend to increase family crises, namely stress. During this pandemic, several families received financial assistance and education funds (in the form of quotas) to 
reduce financial spending, which is one of the stressors (Simanjuntak, Puspitawati, \& Djamaludin, 2008). In addition, with low economic pressure, the relationship between family members will become more harmonious, and the percentage of increased stress will decrease (Masarik et al., 2016).

The subsequent finding is the effect of financial management on QoL. In the case of before the Covid-19 pandemic, the family had managed their finances well, the possibility of the family having a low QoL tended to decline. This is because families can allocate financial resources appropriately, for example, preparing an emergency fund. However, at the beginning of the pandemic, families began to experience financial shocks due to massive job cuts when emergency funds would be used to meet their daily needs. In addition, the need for health funds has also increased, especially if there are families affected by the coronavirus. Research by D'Rummo, Miller, TenNapel, and Shen (2020), Herawati, Simanjuntak, and Kumalasari (2021), and Spencer et al. (2017) found that a decreased QoL could be caused by a poor way of managing family finances because it had an impact on low family survival. Previous research also said that the QoL is measured by financial behavior, life satisfaction, and physical health (Curran, Parrott, Ahn, Serido, \& Shim, 2018).

Based on religiosity and QoL findings, the frequency of worship has nothing to do with improving or reducing the family QoL. Worship alone cannot improve the QoL, so it is necessary to inculcate values in these religious activities. Previous research found that religiosity can predict the emotional and psychological aspects, so it tends to affect life satisfaction rather than the QoL directly (Sabri et al., 2021). In addition, QoL is influenced by complacency and prosperity over the condition and family's facilities (Simanjuntak \& Sabrina, 2015). On the other hand, Rahmah (2018) claims that believing in holy things will motivate the family to improve abilities and reduce negative thoughts, thus enhancing the QoL. In addition, religiosity has a significant positive indirect effect on the family QoL through stress levels. Families that increase the intensity of religiosity during the Covid-19 pandemic will tend to have better mental health, improving or maintaining the quality of family life. Families with a high level of religiosity tend to be more satisfied with their lives because this gives an impression on mental and emotional health (Burlacu et al., 2019; Duarte, Lucchetti, Teixeira, \& Rigatto, 2020).
Research has found that if during the Covid-19 pandemic the family has an excellent ability to manage stress, then the perceived QoL will lead to a positive, and vice versa. Stress is strongly influenced by responsibilities such as roles in work and family, which will impact the family QoL that experience it directly or indirectly. This analysis is in line with previous research conducted by Zainuddin, Utomo, and Herlina (2015), the more a person is depressed (stress), the more their views and perceptions of life will impact the QoL. Maintaining each individual's physical and psychological conditions is the same as maintaining the family structure. Family member experiences a decrease in physical/psychological condition, resulting in a temporary change in roles, functions, and tasks, causing system instability. Individuals who are stressed may feel unsatisfied with their lives due to insecurity (Hsiao et al., 2017; McStay, Trembath, \& Dissanayake, 2014).

The Covid-19 pandemic has increased economic pressure on some families as measured by the difficulty of meeting basic needs and a drastic decrease in income. This study found that economic pressure can have an impact on decreasing QoL. The more economically depressed the QoL will decline (Kumalasari et al., 2018; Yeung \& Xu, 2012). These results indicate that families under economic stress tend to have poor mental health, cognitive function, and a low sense of control. Raharjo, Puspitawati, and Pranaji (2015) found that economic pressure can increase conflict and feelings of depression, decreasing family welfare and QoL. It means that families that can control the pressure, especially the economy, will reduce problems to improve the QoL. In addition, there is a concept that can see the spread of economic pressures and stress levels felt by families during the Covid-19 pandemic through family typology.

Typology of economic pressure is seen based on the distribution of categories of economic pressure and QoL. Type I is the best, namely low economic pressure and high QoL. It means that low economic pressure will lead to a higher QoL. Type II (not optimal) shows that the economic pressure experienced by the family is high, but the family still feels a good or high QoL. Type III or classified as high economic pressure and low QoL. Type IV indicates economic stress and low QoL. It shows that although the economic pressure experienced is joint, they will not significantly impact the Family QoL. It means that other variables can affect the increase in the QoL. Based on the 
distribution of stress levels and QoL, type I is the best type with low-stress levels and high QoL. Type II is a type that is not optimal because the level of family stress is still high. Even though the QoL is also high, families can still enjoy life. Type III is the worst type, and this is because the level of family stress is high and the QoL is low. Finally, type IV presents equally low levels of stress and QoL.

This research has some limitations and can be a reference for future research, including (1) uneven distribution of respondents in all regions in Indonesia, especially the uneven distribution of urban and village areas; (2) the selected analysis unit is the mother who describes the whole family. Further research may include reports of husbands or children over 17 years, so the information obtained would be more complex and based on various points of view; and (3) this study does not use open questions or conduct in-depth interviews. We recommend that similar studies incorporate in-depth interviews to get more detailed answers from the respondents.

\section{CONCLUSION AND SUGGESTION}

Based on the result, it is known that economic pressure, financial management, and stress levels affect the family QoL. Religiosity affects QoL through stress levels. In the typology of economic pressure and QoL, most families tend to meet basic needs, but during the Covid-19 pandemic, families are less able to enjoy life because they are not free to live life. For the typology of stress levels and QoL, most families do not feel stressed, but many are satisfied, and some are dissatisfied with life because many life expectations were not achieved during the Covid-19 pandemic.

Increase the inculcation of positive Muslim values; the Ministry of Religion, which functions as the implementer of education and training to family, can carry out this function through technology such as social media (for example, through content feeds on Instagram). One of the impacts of Covid-19 on the family's economic life is the limited availability of necessities, so many families are stockpiling food in droves. The Ministry of Economy needs to keep the prices of daily necessities from rising significantly and even stagnating or falling. During the Covid-19 pandemic, many micro trader families were affected by the decline in people's purchasing power. The government needs to give leeway to trader families to continue their business and that the unemployment rate does not increase, for example, by not limiting opening hours but limiting the number of people that can transact directly. To control financial conditions, the Financial Services Authority is mandated to provide special education (such as financial allocation by category and the importance of emergency funds) to families about financial literacy and management. In addition, to prevent and avoid stress for the family (both parents and children), the Ministry of Women's Empowerment and Child Protection provides counseling services to families experiencing stress. It encourages parents to educate in a child-friendly way (for example, consistently monitoring and evaluating children's learning activities). Future research is expected to expand the scope of questions or research methods, such as open-ended questions (allowing longer answers) and in-depth interviews. In addition, further research can also measure the QoL more specifically, namely based on subjective and objective, thus generating more specific results.

\section{ACKNOWLEDGMENT}

The authors would like to thank the Study Program of Magister Sciences of Family and Child Development, IPB University

\section{REFERENCES}

Abu-Hilal, M., Al-Bahrani, M., \& Al-Zedjali, M. (2017). Can religiosity boost meaning in life and suppress stress for Muslim college students?. Mental Health, Religion and Culture, 20(3), 203-216. doi:10.1080/13674676.2017.1324835

Ahmad, G. N., Khairunnisa, T. K., \& Gurendawati, E. (2020). Religiusitas, preferensi risiko, locus of control, perilaku keuangan, personal financial distress pada pekerja muda di DKI Jakarta (Religiosity, risk preferences, locus of control, financial behavior, personal financial distress in young workers in DKI Jakarta). Jurnal Riset Manajemen Sains Indonesia (JRMSI), 11(2), 381-403. doi:10.21009/JRMSI.011.2.010

Azizah, R., \& Hartanti, R. D. (2016). Hubungan antara tingkat stress dengan kualitas hidup lansia hipertensi di wilayah kerja puskesmas Wonopringgo Pekalongan (The relationship between stress levels and the quality of life of the elderly hypertension in the working area of Wonopringgo Pekalongan health center). Jurnal University Research Coloquium, 261-278. Retrieved from 
https://publikasiilmiah.ums.ac.id/handle/1 $1617 / 7766$

Bakht, S., \& Batool, S. S. (2018). Original article religiosity and stress as predictors of severity of OCD, and difference in marital adjustment of OCD and non-OCD individuals. Journal of Pakistan Psychiatric Society, 17(3), 19-23. Retrieved from https://jpps.pk/index.php/journal/article/vi $\mathrm{ew} / 49 / 36$

[BPS] Badan Pusat Statistik. (2020). Indeks Pembangunan Manusia (IPM) Indonesia pada tahun 2020 mencapai 71.94 (Indonesia's Human Development Index in 2020 reached 71.94$)$. Retrieved from https://www.bps.go.id/pressrelease/2020/ 12/15/1758/indeks-pembangunanmanusia--ipm--indonesia-pada-tahun2020-mencapai-71-94.html

Bawuna, N., Rottie, J., \& Onibala, F. (2017). Hubungan antara tingkat stres dengan perilaku merokok pada mahasiswa Fakultas Teknik Universitas Sam Ratulangi

(The relationship between stress levels and smoking behavior in students of the Faculty of Engineering, Sam Ratulangi University). Jurnal Keperawatan UNSRAT, 5(2), 107578. Retrieved from https://ejournal.unsrat.ac.id/index.php/jkp /article/view/16844

Buana, D. R. (2020). Analisis perilaku masyarakat Indonesia dalam menghadapi pandemi virus corona (covid-19) dan kiat menjaga kesejahteraan jiwa (Analysis of indonesian behavior in the face of coronavirus pandemic (covid-19) and tips on maintaining mental well-being). SALAM:Jurnal Sosial dan Budaya Syar-I, 7(3), doi:10.15408/sjsbs.v7i3.15082

Burlacu, A., Artene, B., Nistor, I., Buju, S., Jugrin, D., Mavrichi, I., \& Covic, A. (2019). Religiosity, spirituality and quality of life of dialysis patients: A systematic review. International Urology and Nephrology, 51(5), 839-850. doi:10.1007/s11255-019-02129-x

Carroll, N., Sadowski, A., Laila, A., Hruska, V., Nixon, M., Ma, D. W. L., \& Haines, J. (2020). The impact of covid-19 on health behavior, stress, financial and food security among middle to high income Canadian families with young children.
Nutrients,
12(8),
$1-14$. doi:10.3390/nu12082352

Chae, W., Park, E. C., \& Jang, S. I. (2020). The association between the changes in general, family, and financial aspects of quality of life and their effects on cognitive function in an elderly population: The Korean longitudinal study of aging, 2008-2016. International Journal of Environmental Research and Public Health, 17(3), 1-12. doi:10.3390/ijerph17031106

Curran, M. A., Parrott, E., Ahn, S. Y., Serido, J., \& Shim, S. (2018). Young adults' life outcomes and well-being: Perceived financial socialization from parents, the romantic partner, and young adults' own financial behaviors. Journal of Family and Economic Issues, 39(3), 445-456. doi:10.1007/s10834-018-9572-9

D’Rummo, K. A., Miller, L., TenNapel, M. J., \& Shen, X. (2020). Assessing the financial toxicity of radiation oncology patients using the validated comprehensive score for financial toxicity as a patient-reported outcome. Practical Radiation Oncology, 10(5), doi:10.1016/j.prro.2019.10.005 322-329.

Duarte, A. A. M., Lucchetti, G., Teixeira, P. J. Z., \& Rigatto, K. (2020). Spirituality and religiosity are associated with quality of life in patients with lung disease. Journal of Religion and Health, 59(4), 18431854. doi:10.1007/s10943-018-0735-7

Gibson, J., \& Olivia, S. (2020). Direct and indirect effects of covid-19 on life expectancy and poverty in Indonesia. Bulletin of Indonesian Economic Studies, 56(3), 325-344. doi:10.1080/00074918.2020.1847244

Hakim, F. A., Sunarti, E., \& Herawati, T. (2014). Families with husband and wife work financial management and wife's financial satisfaction of dual earner families abstract. Jurnal IImu Keluarga dan Konsumen, 7(3), 174-182. doi:10.24156/jikk.2014.7.3.174

Hanoatubun, S. (2020). Dampak covid-19 terhadap perekonomian Indonesia (Impact of Covid-19 on Indonesia's economy). Journal of Education, Psychology and Counseling, 2(1), 146153. Retrieved from https://ummaspul.ejournal.id/Edupsycouns/article/view/423

Herawati, T., Ginting, B., Asngari, P. S., Susanto, D., \& Puspitawati, H. (2011). 
Ketahanan pangan keluarga peserta program pemberdayaan masyarakat di pedesaan (Food security of families participating in community empowerment programs in the countryside). Jurnal Gizi Dan Pangan, 6(3), 208. doi:10.25182/jgp.2011.6.3.208-216

Herawati, T., Simanjuntak, M., \& Kumalasari, B. (2021). Investigating the quality of life on farmer family: Roles of gender relations, economic pressure, financial management, and livelihood strategies. Journal of Family Sciences, 06(01), 3752. doi:10.29244/jfs.v6i1.35796

Hsiao, Y. J., Higgins, K., Pierce, T., Whitby, P. J. S., \& Tandy, R. D. (2017). Parental stress, family quality of life, and familyteacher partnerships: Families of children with autism spectrum disorder. Research in Developmental Disabilities, 70, 152 162. doi:10.1016/j.ridd.2017.08.013

Khodijah, N. (2018). Pendidikan karakter dalam Kultur Islam Melayu: Studi terhadap pola asuh orang tua, faktorfaktor yang mempengaruhinya, dan pengaruhnya terhadap religiusitas remaja pada Suku Melayu Palembang (Character education in Malay Islamic culture: Tthe study of parental parenting, factors that influence it, and its effect on adolescent religiosity in Palembang Malay Tribes). Tadrib: Jurnal Pendidikan Agama Islam, 4(1), 21-39. doi:10.19109/tadrib.v4i1.1949

Kumalasari, B., Herawati, T., \& Simanjuntak, M. (2018). Gender relations, economic pressures, financial management. Jurnal Ilmu Keluarga dan Konsumen, 11(2), 108-119.

doi:10.24156/jikk.2018.11.2.108

Lady, L., Susihono, W., \& Muslihati, A. (2017). Analisis tingkat stres kerja dan faktorfaktor penyebab stres kerja pada pegawai BPBD Kota Cilegon (Analysis of work stress levels and factors that cause work stress in BPBD employees of Cilegon City). Journal Industrial Servicess, 3(1b), 191-197. Retrieved from

http://jurnal.untirta.ac.id/index.php/jiss/arti cle/view/2084

Lajuni, N., Bujang, I., Karia, A. A., \& Yacob, Y. (2018). Religiosity, financial knowledge, and financial behavior influence on personal financial distress among millennial generation. Jurnal Manajemen
Dan Kewirausahaan, 20(2), 92-98. doi:10.9744/jmk.20.2.92-98

Lorenz, F. O., Conger, R. D., \& Montague, R. (2020). Doing worse and feeling worse: Psychological consequences of economic hardship. In Families in troubled times (pp. 167-186). Routledge.

Masarik, A. S., Martin, M. J., Ferrer, E., Lorenz, F. O., Conger, K. J., \& Conger, R. D. (2016). Couple resilience to economic pressure over time and across generations. Journal of Marriage and Family, 78(2), doi:10.1111/jomf.12284

Maulana, H. A., \& Iswari, R. D. (2020). Analisis tingkat stres mahasiswa terhadap pembelajaran daring pada mata kuliah statistik bisnis di pendidikan vokasi (Analysis of student stress levels of online learning in business statistics courses in vocational education). Khazanah Pendidikan, 14(1), 17-30. doi:10.30595/jkp.v14i1.8479

Maryam, S. (2017). Stres keluarga: Model dan pengukurannya (Family stress: Models and measurements). Psikoislamedia J. Psikol. 1(2), 335-343. doi:10.22373/psikoislamedia.v1i2.920.

McStay, R. L., Trembath, D., \& Dissanayake, C. (2014). Stress and family quality of life in parents of children with autism spectrum disorder: Parent gender and the double ABCX model. Journal of Autism and Developmental Disorders, 44(12), 3101-3118. doi:10.1007/s10803014-2178-7

Megawaty. (2016). Pengaruh religiusitas dan dukungan sosial terhadap kualitas hidup penderita kanker serviks (The influence of religiosity and social support on the quality of life of cervical cancer patients). Tazkiya Journal of Psychology, 4(2), 111-125. Retrieved from http://journal.uinjkt.ac.id/index.php/tazkiy a/article/viewFile/10842/5579

Muhammad, L. Y. B., Muflikhati, I., \& Simanjuntak, M. (2019). Religiusitas, dukungan sosial, stres, dan penyesuaian wanita bercerai (Religiosity, social support, stress, and adjustment of divorced women). Jurnal Ilmu Keluarga dan Konsumen, 12(3), 194-207. doi:10.24156/jikk.2019.12.3.194

Nusron, L., Wahidiyah, M., \& Budiarto, D. (2018). Antecedent factors of financial management behavior: An empirical 
research based on education. KnE Social Sciences, 3(10), 437-445. doi:10.18502/kss.v3i10.3146

[OECD] Organization for Economic Cooperation and Development. (2021). Purchasing power parities (PPP) (indicator). doi:10.1787/1290ee5a-en

Pace, D. S. (2021). Probability and nonprobability sampling-an entry point for undergraduate researchers. International Journal of Quantitative and Qualitative Research Methods, 9(2), 1-15. Retrieved from https://ssrn.com/abstract=3851952

Pajarianto, H., Kadir, A., Galugu, N., Sari, P., \& Februanti, S. (2020). Study from home in the middle of the covid-19 pandemic: Analysis of religiosity, teacher, and parents support against academic stress. Journal of Talent Development and Excellence, 12(2), 1791-1807. Retrieved from http://iratde.com/index.php/jtde

Puspitawati, H. (2012). Gender dan keluarga: Konsep dan realita di Indonesia (Gender and family: Concepts and realities in Indonesia). Bogor: IPB Press. doi:10.1017/S0033583501003705

Raharjo, I. T., Puspitawati, H., \& Pranaji, D. K. (2015). Tekanan ekonomi, manajemen keuangan, dan kesejahteraan pada keluarga muda (Economic, financial management, and well-being pressures on young families). Jurnal IImu Keluarga dan Konsumen, 8(1), 38-48. doi:10.24156/jikk.2015.8.1.38

Rahmah, H. (2018). Pengaruh dukungan sosial dan religiusitas terhadap kualitas hidup remaja penyandang disabilitas fisik (The effect of social support and religiosity on the quality of life of adolescents with physical disabilities). Al Qalam: Jurnal IImiah Keagamaan dan Kemasyarakatan, 11(23), doi:10.35931/aq.v0i0.2

Rosino, M. (2016). ABC-X model of family stress and coping. Encycl. Fam. Stud. 16. doi:10.1002/9781119085621.wbefs313.

Sabri, M. F., Dass, T. M., Burhan, N. A. S., Wahab, H. A. R. A., Wijekoon, R., \& Simanjuntak, M. (2021). Determinants of life satisfaction among female-headed households in Malaysia. International Journal of Business and Society, 22(1), 276-295. doi:10.33736/ijbs.3175.2021

Sakellari, E., Psychogiou, M., Georgiou, A., Papanidi, M., Vlachou, V., \& Sapountzi-
Krepia, D. (2017). Exploring religiosity, self-esteem, stress, and depression among students of a Cypriot university. Journal of Religion and Health, 57(1), 136-145. doi:10.1007/s10943-017-04104

Sarrasin, O., Green, E. G. T., Potarca, G., Bolzman, C., \& Kuhn, U. (2019). Feeling blue by extension: Intrafamily transmission and economic pressures explain the native-immigrant gap in wellbeing among youth in Switzerland. Social Inclusion, 7(4), 293-303. doi:10.17645/si.v7i4.2344

Simanjuntak, M., Puspitawati, H., \& Djamaludin, M. (2008). Faktor-faktor yang mempengaruhi kesejahteraan keluarga subjektif penerima Program Keluarga Harapan (PKH) (Factors that affect the subjective family well-being of recipients of the Family Hope Program (PKH)). Media Gizi \& Keluarga, 32(2), 30-39. Retrieved from https://repository.ipb.ac.id/bitstream/handl e/123456789/76850/\%5Bcompressed\%5 D Jurnal Media Gizi 2.pdf? sequence $=1$ \&isAllowed $=y$

Simanjuntak, M., \& Sabrina, O. (2015). Apakah kepribadian, kekosmopolitan, dan orientasi nilai menentukan kualitas hidup subjektif keluarga? (Do personality, monopolism, and value orientation determine a family's subjective quality of life?). Jurnal IImu Keluarga dan Konsumen, 8(3), 173-181. doi:10.24156/jikk.2015.8.3.173

Spencer, J., Reeder-Hayes, K. E., Pinheiro, L. C., Carey, L. A., Olshan, A. F., \& Wheeler, S. B. (2017). Short and long term impact of financial toxicity on quality of life in the Carolina Breast Cancer study. Journal of Clinical Oncology, 35(15). doi:10.1200/jco.2017.35.15_suppl.e1829 9

Stein, C. H., Hoffmann, E., Bonar, E. E., Leith, J. E., Abraham, K. M., Hamill, A. C., Kraus, S. W., Gumber, S., \& Fogo, W. R. (2013). The United States economic crisis: Young adults' reports of economic pressures, financial and religious coping and psychological well-being. Journal of Family and Economic Issues, 34(2), 200210. doi:10.1007/s10834-012-9328-X

Syafitri, D. U., \& Hadjam, M. N. R. (2017). Religiusitas: Faktor protektif pengasuhan orangtua dengan status sosial ekonomi 
rendah (Religiosity: Protective factors of parental parenting with low socioeconomic status). Psikologika: Jurnal Pemikiran Dan Penelitian Psikologi, 22(2), 1-14. doi:10.20885/psikologika.vol22.iss2.art1

Syah, R. H. (2020). Dampak covid-19 pada pendidikan di Indonesia: Sekolah, keterampilan, dan proses pembelajaran (Impact of covid-19 on education in Indonesia: Schools, skills, and learning processes). SALAM: Jurnal Sosial dan Budaya Syar-l, 7(5), 395-402. doi:10.15408/sjsbs.v7i5.15314

[WHO] World Health Organization. (2021). Coronavirus. Retrieved from https://www.who.int/healthtopics/coronavirus\#tab=tab_1

[WHO] World Health Organization. (2020). WHOQOL: Measuring Quality of Life. Retrieved https://www.who.int/healthinfo/survey/wh oqol-qualityoflife/en/

Yeung, W. J., \& Xu, Z. (2012). Economic stress, quality of life, and mortality for the oldest-old in China. Social Indicators Research, 108(1), 131-152. doi:10.1007/s11205-011-9870-1

Zainuddin, M., Utomo, W., \& Herlina. (2015). Hubungan stres dengan kualitas hidup penderita diabetes mellitus tipe 2 (The relationship of stress with the quality of life of people with type 2 diabetes mellitus). Jurnal Online Mahasiswa Program Studi IImu Keperawatan Universitas Riau, 2(1), 890-898. Retrieved from https://www.neliti.com/publications/188 387/hubungan-stres-dengan-kualitashidup-penderita-diabetes-mellitus-tipe-2 